\title{
Road-killed wild animals: a preservation problem useful for eco- epidemiological studies of pathogens
}

Richini-Pereira VB (1), Bosco SMG (2), Theodoro RC (2), Barrozo L (3), Bagagli E (2)

(1) Department of Veterinary Hygiene and Public Health, School of Veterinary Medicine and Animal Husbandry, São Paulo State University (UNESP - Univ Estadual Paulista), Botucatu, São Paulo State, Brazil; (2) Department of Microbiology and Immunology, Botucatu Biosciences Institute, São Paulo State University (UNESP - Univ Estadual Paulista), Botucatu, São Paulo State, Brazil; (3) Department of Geography, School of Philosophy, Literature and Human Sciences, University of São Paulo, São Paulo, São Paulo State, Brazil.

\begin{abstract}
Road-killed wild animals have been for years used for surveillance of vectors of zoonotic pathogens and may offer new opportunities for eco-epidemiological studies. In the current study, fungal infection was evaluated by PCR and nested-PCR in tissue samples collected from 19 road-killed wild animals. The necropsies were carried out and samples were collected for DNA extraction. Results, using PCR with a panfungal primer and nested PCR with specific primers, indicated that some animals are naturally infected with Amauroascus aureus, Metarhizium anisopliae, Aspergillus flavus, Aspergillus oryzae, Emmonsia parva, Paracoccidioides brasiliensis or Pichia stipitis. The approach employed herein proved useful for detecting the environmental occurrence of several fungi, as well as determining natural reservoirs in wild animals and facilitating the understanding of host-pathogen relationships.
\end{abstract}

Key words: road-killed animals, fungal pathogens, eco-epidemiology, PCR.

\section{INTRODUCTION}

Environmental changes and ecological disturbances caused by natural phenomena or human intervention are considered important factors in the emergence and reemergence of diseases and have generated both interest in research and concern about the global biodiversity conservation. The causal factors that are associated with this vulnerability and facilitate the transmission of infectious agents include: population growth and consequent human migration, introduction of animals into new habitats or their absence, changes in the distribution of hosts and vectors, and increased interaction between humans and the wild life (15).

Studies involving wild animals are increasingly restrictive, especially concerning methods that require anesthesia and/or euthanasia. Thus, molecular detection of fungal pathogens in road-killed wild animals fulfills the need of searching for alternatives to the use of animals in research, as indicated by animal experimentation ethics committees. The number and diversity of animals killed in Brazilian roads yearly increases and this problem worsens mainly due to the car flow augmentation and highways crossing areas potentially rich in fauna and flora, which interferes with the natural migration of species (6-8). Therefore, the road-killing has contributed to the decline of wild mammal populations and to difficulties in their recovery, especially for those at risk of extinction (9). Biological conservation studies have been conducted, mainly quantitative and qualitative surveys on the roadkill rate $(7,8$, 10-12). However, there are a few works emplying animal carcasses for further investigation such as in helminthological, epidemiological, morphological and genetic studies (13-17).

Although culture and histopathological analysis of tissue samples from road-killed 
animals are complex, molecular techniques may be used in the identification and typing of pathogens through PCR (polymerase chain reaction) with specific primers, presenting high specificity and sensitivity to a certain fragment of the pathogen specific DNA (18).

Several targets within the fungal genome have been evaluated, especially sequence areas in the ribosomal DNA (rDNA) $(19,20)$. This genome region is important to detect and identify pathogenic fungi since it contains nucleotide sequences relatively preserved among fungi besides variable regions known as "internal transcribed spacers" (ITS), which are used to differentiate between species or strains of the same species (21-23). As this region presents hundreds of copies per genome, it provides higher sensitivity and specificity, representing an important target for fungal identification.

Another potent tool for epidemiological studies is the use of geographic information systems (GIS), which have been extensively employed to analyze the geographic distribution and the dynamics of several diseases of varied etiologies, including coccidioiodomycosis, blastomycosis and paracoccidioidomycosis (24-30). The importance of this database has direct implications in epidemiological studies since it allows data to be interactively accessed, transformed and updated, facilitating the analysis of relationships between occurrences and mapped environmental characteristics, which makes possible the identification and the delimitation of areas at risk of infection (31).

Thus, research into new hosts by combining molecular biology techniques and applying geoprocessing are distinctive in ecoepidemiological studies of pathogens.

\section{MATERIALS AND METHODS}

\section{Evaluated Animals and Sampling}

Without the necessity of applying a laborious sampling effort, we evaluated 19 road-killed wild animals: one Callithrix penicillata (A1), one Cavia aperea (A2), one Cebus apella (A3), four Cerdocyon thous (A4-A7), two Dasypus novemcinctus (A8-A9), one Didelphis albiventris (A10), one Leporidae (A11), two Lutreolina crassicaudata (A12-A13), one Mazama gouazoubira (A14), one Myocastor coypus (A15), one Procyon cancrivorus (A16), one Puma concolor (A17) and two Sphiggurus spinosus (A18-A19). Only recently dead animals (1-7 hours) and those with no exposed viscera were collected. They were identified to the highest possible taxonomic level. Necropsy was carried out and organ fragments were stored in microtubes at $-80^{\circ} \mathrm{C}$ until processing for DNA extraction. This study is in accordance with IBAMA's normative statement n. 119 of October 11, 2006, Chapter VI, Article 26, which authorizes the collection and transport of animals that were found dead for scientific or didactic purposes. The current study was also approved by the Ethics Committee on Animal Experimentation of the Botucatu Biosciences Institute, UNESP (n. 052/05).

\section{Molecular Evaluation}

DNA extraction from animal tissue samples was carried out by using the Illustra ${ }^{\varpi}$ Tissue \& Cells Genomic Prep Mini Spin kit (GE Healthcare, UK). PCR reactions were performed by employing the universal primers ITS4/ITS5 for fungi that have shown promising results for studies on the environmental occurrence of pathogens (32). For P. brasiliensis specific amplification, nested PCR was carried out with the primers PbITSE/PbITSR (33).

The obtained amplicons were purified using the Illustra ${ }^{\oplus}$ DNA and Gel Band Purification kit (GE Healthcare, UK). Sequencing was performed to verify the identity of the amplicons obtained by PCR reactions with pathogen sequences stored in the GenBank database. Sequencing reactions were done in the automatic sequencer MegaBace ${ }^{\oplus}$ 1000 (GE Healthcare, USA).

The obtained sense and antisense sequences were visualized (Chromas 2.3 software, Technelysium Pty Ltd, Australia), aligned by the MEGA4 software (34), subjected to BLASTn (http://www.ncbi.nlm.nhi.gov/BLAST) and compared with the sequences stored in the databanks.

\section{Ecological Studies and Application of Geographic Information System}

The exact geographic location of each animal was established with Global Positioning System (GPS) and inserted in a digital databank using geo-referenced interface. 


\section{RESULTS}

Table 1 displays the results of the sequencing reactions carried out by using amplicons from
PCR reactions positive for fungal DNA in the evaluated road-killed animals and nested PCR for amplicons specific for P. brasiliensis.

Table 1. Geographic distribution of animals that revealed positive DNA amplification for fungi in PCR reaction

\begin{tabular}{|c|c|c|c|}
\hline Animal & Geographic location & Species & Amplicon \\
\hline $\mathrm{A} 2$ & $\begin{array}{l}22^{\circ} 36^{\prime} 19.20^{\prime \prime S} \\
48^{\circ} 09^{\prime} 50.93^{\prime \prime} \mathrm{W}\end{array}$ & C. aperea & Pichia stipitis \\
\hline A8 & $\begin{array}{l}23^{\circ} 00^{\prime} 46.64^{\prime \prime} \mathrm{S} \\
48^{\circ} 30^{\prime} 28.59^{\prime \prime} \mathrm{W}\end{array}$ & D. novemcinctus & $\begin{array}{l}\text { P. brasiliensis* } \\
\text { Emmonsia parva }\end{array}$ \\
\hline A9 & $\begin{array}{l}22^{\circ} 53^{\prime} 09.20^{\prime \prime} \mathrm{S} \\
48^{\circ} 27^{\prime} 35.59^{\prime \prime} \mathrm{W}\end{array}$ & D. novemcinctus & $\begin{array}{c}\text { P. brasiliensis }{ }^{* *} \\
\text { Aspergillus flavus or } A \text {. oryzae }\end{array}$ \\
\hline A16 & $\begin{array}{l}22^{\circ} 43^{\prime} 20.41^{\prime \prime S} \\
48^{\circ} 37^{\prime} 49.99^{\prime \prime} \mathrm{W}\end{array}$ & P. cancrivorus & P. brasiliensis \\
\hline A18 & $\begin{array}{l}23^{\circ} 01^{\prime} 53.00^{\prime \prime} \mathrm{S} \\
48^{\circ} 04^{\prime} 53.19^{\prime \prime} \mathrm{W}\end{array}$ & S. spinosus & $\begin{array}{c}\text { Amauroascus aureus or Metarhizium anisopliae } \\
\text { P. brasiliensis* }\end{array}$ \\
\hline A19 & $\begin{array}{l}22^{\circ} 49^{\prime} 58.71^{\prime \prime S} \\
48^{\circ} 25^{\prime} 24.75^{\prime \prime} \mathrm{W}\end{array}$ & S. spinosus & P. brasiliensis \\
\hline
\end{tabular}

*A8 and A18: P. brasiliensis amplicon references (17).

** A9: P. brasiliensis amplicon reference (35).

\section{DISCUSSION}

The present study focused on the molecular analysis of road-killed wild animals which may represent a viable alternative to the use of experiment animals in research, as suggested by animal research ethics committees. During our study, we were able to find a great diversity of road-killed wild mammal species. A research exclusively aimed at surveying road-killed animal species certainly contributes to adapt road infrastructures concerning the care with the fauna.

Works on conservation biology using roadkilled species have indicated that $75 \%$ of deaths in roads include animals in good or excellent health conditions (36). In the present study, necropsy demonstrated no apparent macroscopic change that would indicate pathological processes in the examined samples. As culture analysis and histopathology are difficult, sensitive and specific molecular tools were employed to allow the identification of pathogens, without the need of culturing, as suggested by San-Blas et al. (37).
Four Canidae specimens, belonging to the species $C$. thous (crab-eating fox), were evaluated in the current study. This species presents generalist feeding habit, preferably nocturnal, moving through trails at forest edges and surviving in degraded and anthropic areas (38). It can be frequently seen at highway edges searching for food including the remains of other road-killed animals; thus, $C$. thous is a frequent victim of roadkill $(10,39,40)$. No pathogenic fungus was detected in this animal group.

The family Procyonidae was represented by one specimen, namely Procyon cancrivorus (crabeating raccoon), which inhabits tropical and equatorial forests, always close to rivers, bogs, swamps and marshes. It has nocturnal habits and is a good swimmer and climber. Its diet is omnivorous and basically consists of wild fruits, invertebrates and small vertebrates (41). In the current study, $P$. brasiliensis DNA was detected in the lungs of $P$. cancrivorus, which corroborates our previous works (17). This fact confirms that this mainly an airborne fungus, and it did not disseminate (42). 
As regards the families Cervidae (one $M$. gouazoubira - brown brocket deer), Leporidae (one hare), Felidae (one P. concolor - cougar) and Cebidae (one C. apella - capuchin monkey and one C. penicillata - black-tufted-ear marmoset), fungal DNA was not detected, which is not indicative that these groups of animals did not become infected since the evaluation included only one specimen of each species. Again, fungal DNA was not detected in samples from one specimen of the Didelphidae family. The members of this family, represented by $D$. albiventris specimens (white-eared opossums), have generalist habit and currently occur in areas near human dwellings, including farms, yards and urban centers (43). This animal is considered a reservoir for several diseases of zoonotic potential (44). However, marsupials seem to be infrequently infected by $P$. brasiliensis or they may efficiently blocked the infection, which makes $D$. albiventris an improbable host for this fungus, as previously described (45).

Rodents were represented by two S. spinosus (porcupine) and one M. coypus (coypu). In a previous work, rodents were evaluated and $P$. brasiliensis DNA was detected in $S$. spinosus and Cavia aperea tissue samples from paracoccidioidomycosis endemic areas of Botucatu, Brazil (22056'39.26”S/48 23'10.64”W) and Conchas $\left(23^{\circ} 01^{\prime} 53.00^{\prime \prime} \mathrm{S} / 48^{\circ} 04^{\prime} 53.19^{\prime \prime} \mathrm{W}\right)$ cities, Brazil, being present in several organs (liver, spleen, kidneys, adrenal glands and mesenteric lymph node), which indicates that the fungus overcame the primary barrier, the lungs, and disseminated (17). In the current study, one animal ( $S$. spinosus) tested positive, which reveals an increasing number of positive results for this group. These findings corroborate those already described in the literature and show the importance of this animal group as reservoirs of several pathogens (46). Some rodent species are considered reservoirs of Coccidioides immitis and Penicillium marneffei; similarly, the rodents Calomys callosus have been recently described as susceptible to experimental infection with $P$. brasiliensis (47-50).

The result obtained in the sequencing of ITS5.8S region with universal primers for ITS4/ ITS5 fungi, from the amplicon found in the lungs of a S. spinosus (porcupine), corroborates that the animal was exposed to more than one fungus. The similar percentages of Amauroascus aureus and Metarhizium anisopliae, respectively 87 and 85\%, may have been low because the gene sequence of the species corresponding to the obtained amplicon has not been stored in GenBank yet. Although not totally conclusive, the finding involving A. aureus is interesting, since this fungus is little known as to its biological significance. Similarly, the non-pathogenic fungus Pichia stipitis was probably detected because the gene sequence of the species corresponding to the amplicon has not been deposited in GenBank, or there might be a relationship of symbiosis or commensalism between this fungus and the guinea pig.

Armadillos present fossorial-terrestrial, crepuscular/nocturnal habits. They are asocial and spend their life building burrows, and digging in search for food (51). D. novemcinctus (nine-banded armadillo) have slow movement and are not very agile; besides, their hearing is not very accurate and their vision is relatively little developed, which can make them blinded by the car lights while crossing roads (52).

There is strong evidence that the number of road-killed armadillos is even larger than that reflected by the collected specimens since the workers of the Department of Highways have reported that these animals are commonly seen crossing the highways in Botucatu region. We probably did not find a larger number of this species because armadillo meat is highly appreciated and recently killed animals can be rapidly removed from the roads for human consumption. A lung sample from an armadillo analyzed by PCR was then purified and sequenced, confirming that the amplicon corresponded to Emmonsia parva DNA. The species E. parva and E. crescens are the main causative agents of adiaspiromycosis, a mycosis that, differently from those caused by Onygenales fungi, do not disseminate in the host, being restricted to the lung tissue. The genus Emmonsia belongs to the family Onygenaceae (sensu lato), which includes the remaining dimorphic pathogenic fungi causing the main systemic mycosis. The main pathogens of the family Onygenaceae present localized geographic distribution, concentrating in the Americas; however, Emmonsia is widespread. As observed for the remaining dimorphic fungi of the order Onygenales, the soil seems to constitute the main habitat of Emmonsia spp. Studies have shown that its occurrence is related to dense forest areas, with 
abundant plant remnants (53). Several works have reported the presence of this fungus in wild and domestic rodents, carnivores and armadillos (5356). Rodent burrows have been pointed out as the main habitats of the fungus since it is present in the soil and is frequently detected in these animals. Thus, our finding of Emmonsia parva infection in armadillos from the studied region is novel and still scarcely explored.

The present results show the problem of the large number of wild animals killed in our highways, emphasizing the importance of using this biological resource in eco-epidemiological studies of fungal pathogens.

\section{ACKNOWLEDGEMENTS}

This work was supported by the State of São Paulo Research Foundation (FAPESP). We are the grateful to the Department of Highways of São Paulo State (DER), as well as to Prof. Dr. Reinaldo José da Silva and Juliana Griese for information on the road-killed animals.

\section{COPYRIGHT}

(c) CEVAP 2010

\section{SUBMISSION STATUS}

Received: May 27, 2010.

Accepted: September 20, 2010.

Abstract published online: September 23, 2010.

Full paper published online: November 30, 2010.

\section{CONFLICTS OF INTEREST}

There is no conflict.

\section{FINANCIAL SOURCE}

The State of São Paulo Research Foundation (FAPESP) provided the financial grants (processes n. 05/56771-9 and 06/03597-4).

\section{ETHICS COMMITTEE APPROVAL}

The present study was approved by the Ethics Committee on Animal Experimentation of the Botucatu Biosciences Institute of the São Paulo State University (protocol n. 052/05-CEEA) and also agrees with The Brazilian Institute of Environment and Renewable Natural Resources (IBAMA) regulations.

\section{CORRESPONDENCE TO}

VIRGÍNIA BODELÃO RICHINI-PEREIRA, Departamento de Higiene Veterinária e Saúde
Pública, Faculdade de Medicina Veterinária e Zootecnia, UNESP, Distrito de Rubião Junior, s/n, Botucatu, SP, 18618-970, Brasil. Phone: +55 143811 6070. Email: virichini@yahoo.com.br.

\section{REFERENCES}

1. Daszak P, Cunningham AA, Hyatt AD. Emerging infectious diseases of wildlife threats to biodiversity and human health. Science. 2000;287(5452):443-9.

2. Daszak P, Epstein JH, Kilpatrick AM, Aguirre AA, Karesh WB, Cunningham AA. Collaborative research approaches to the role of wildlife in zoonotic disease emergence. Curr Top Microbiol Immunol. 2007;315(1):463-75.

3. Patz JA, Graczyk TK, Geller N, Vittor AY. Effects of environmental change on emerging parasitic diseases. Int J Parasitol. 2000;30(12-13):1395405.

4. Bengis RG, Leighton FA, Fischer JR, Artois M, Mörner T, Tate CM. The role of wildlife in emerging and re-emerging zoonoses. Rev Sci Tech. 2004;23(2): 497-511.

5. Jones KE, Patel NG, Levy MA, Storeygard A, Balk $\mathrm{D}$, Gittleman JL, et al. Global trends in emerging infectious diseases. Nature. 2008;451(1):990-3.

6. Forman RTT, Alexander LE. Roads and their major ecological effects. Annu Rev Ecol Evol Syst. 1998;29(1):207-31.

7. Rodrigues FHG, Hass A, Rezende LM, Pereira CS, Figueiredo DF, Leite BF, et al. Impacto de rodovias sobre a fauna da estação ecológica de Águas Emendadas, DF. In: Congresso Brasileiro de Unidades de Conservação, 3, Fortaleza, 2002. p. 585-93.

8. Prada CS. Atropelamento de vertebrados silvestres em uma região fragmentada no nordeste do estado de São Paulo: quantificação do impacto e análise de fatores envolvidos [dissertation]. São Carlos: Centro de Ciências Biológicas e da Saúde, Universidade Federal de São Carlos; 2004. 129 p.

9. Trombulak SC, Frissel CA. Review of ecological effects of roads on terrestrial and aquatic communities. Conserv Biol. 2000;14(1):18-30.

10. Vieira EM. Highway mortality of mammals in central Brazil. J Braz Assoc Adv Sci. 1996;48(4):2702.

11. Candido Jr JF, Margarido VP, Pegoraro JL, D’Amico AR, Madeira WD, Casale VC, et al. Animais atropelados na rodovia que margeia o Parque Nacional do Iguaçu, Paraná, Brasil, e seu aproveitamento para estudos da biologia da conservação In: III Congresso Brasileiro de Unidades de Conservação, 3, Fortaleza; 2002. p. 553-62. 
12. Pinowski J. Roadkills of vertebrates in Venezuela. Rev Bras Zootec. 2005;22(1):191-6.

13. Coyner DF, Wooding JB, Forrester DJ. A comparison of parasitic helminthes and arthropods from two subspecies of fox squirrels (Sciurus niger) in Florida. J Wild Dis. 1996;32(3):492-7.

14. Foster GW, Main MB, Kinsella JM, Dixon LM, Terrell SP, Forrester DJ. Parasitic helminths and arthropods of coyotes (Canis latrans) from Florida, USA. Comp Parasitol. 2003;70(2):162-6.

15. Nelder MP, Reeves WK. Ectoparasites of roadkilled vertebrates in northwestern South Carolina, USA. Vet Parasitol. 2005;129(3-4):313-22.

16. Griese J. Helmintofauna de vertebrados atropelados em rodovias da região de Botucatu, São Paulo [dissertation]. Botucatu: Instituto de Biociências, Universidade Estadual Paulista; 2007. 68 p.

17. Richini-Pereira VB, Bosco S de M, Griese J, Theodoro RC, Macoris SA, da Silva RJ, et al. Molecular detection of Paracoccidioides brasiliensis in road-killed wild animals. Med Mycol. 2008;46(1):35-40.

18. Persing DH, Smith TF, Tenover FC, White TJ. Fungal pathogens. In: Persing DH, Smith TF, Tenover FC, White TJ, editors. Diagnostic molecular microbiology: principles and applications. Washington: American Society for Microbiology; 1993. p. 423-37.

19. Anderson IC, Chambers SM, Cairney JWG. ITSRFLP and ITS sequence diversity in Pisolithus from central and eastern Australian sclerophyll forests. Mycol Res. 2001;105(11):1304-12.

20. Uetake Y, Arakawa M, Nakamura H, Akahira T, Sayama A, Cheah LH, et al. Genetic relationship among violet root rot fungi as revealed by hyphal anastomosis and sequencing of the rDNA ITS regions. Mycol Res. 2002;106(2):156-63.

21. Esteve-Zarzoso B, Belloch C, Uruburu F, Querol A. Identification of yeasts by RFLP analysis of 5.8S rRNA gene and the two ribosomal internal transcribed spacers. Int J Syst Bacteriol. 1999;49(1):329-37.

22. Henry T, Iwen PC, Hinrichs SH. Identification of Aspergillus species using internal transcribed spacer regions 1 and 2. J Clin Microbiol. 2000;38(4):1510-5.

23. Iwen PC, Hinrichs SH, Rupp ME. Utilization of the internal transcribed spacer regions as molecular targets to detect and identify human fungal pathogens. Med Mycol. 2002;40(1):87-109.

24. Linthicum KJ, Bailey CL, Davies FG, Tucker CJ. Detection of Rift Valley fever viral activity in Kenya by satellite remote sensing imagery. Science. 1987;235(4796):1656-9.
25. Rogers DJ, Randolph SE. Mortality rates and population density of tsetse flies correlated with satellite imagery. Nature. 1991;351(1):739-41.

26. Beck LR, Rodriguez MH, Dister SW, Rodriguez $\mathrm{AD}$, Rejmankova E, Ulloa A, et al. Remote sensing as a landscape epidemiologic tool to identify villages at high risk for malaria transmission. Am J Trop Med Hyg. 1994;51(3):271-80.

27. Baptista-Rosas RC, Hinojosa A, Riquelme M. Ecological niche modeling of Coccidioides spp. in Western North American deserts. Ann N Y Acad Sci. 2007;1111(1):35-46.

28. Reed KD, Meece JK, Archer JR, Peterson AT. Ecologic niche modeling of Blastomyces dermatitidis in Wisconsin. PLoS ONE. 2008;3(4):e2034.

29. Simões LB, Marques SA, Bagagli E. Distribution of paracoccidioidomycosis: determination of ecologic correlates through spatial analyzes. Med Mycol. 2004;42(6):517-23.

30. Barrozo LV, Mendes RP, Marques SA, Benard G, Silva ME, Bagagli E. Climate and acute/subacute paracoccidioiomycosis in a hyper-endemic area in Brazil. Int J Epidemiol. 2009;38(6):1642-9.

31. Martin V, De Simone L, Lubroth J, Ceccato P, Chevalier V. Perspectives on using remotelysensed imagery in predictive veterinary epidemiology and global early warning systems. Geospat Health. 2007;2(1):3-14.

32. White TJ, Brunis T, Lee S, Taylor J. Amplification and direct sequencing of fungal ribossomal RNA genes for phylogenetics. In: Innis MA, Gelfand DH, Sninsky JJ, White TJ, editors. PCR protocols: A guide to methods and applications. San Diego: Academic Press, Inc.;1990. p. 315-22.

33. Theodoro RC, Candeias JM, Araújo JP Jr, Bosco S de M, Macoris SA, Padula LO, et al. Molecular detection of Paracoccidioides brasiliensis in soil. Med Mycol. 2005;43(8):725-9.

34. Tamura K, Dudley J, Nei M, Kumar S. MEGA4: Molecular Evolutionary Genetics Analysis (MEGA) software version 4.0. Molec Biol Evol. 2007;24:1596-1599.

35. Richini-Pereira VB, Bosco SM, Theodoro RC, Barrozo L, Pedrini SC, Rosa PS, et al. Importance of xenarthrans in the eco-epidemiology of Paracoccidioides brasiliensis. BMC Res Notes. 2009;2(1):228.

36. Nettles VF, Quist CF, Lopez RR, Wilmers TJ, Frank P, Roberts W, et al. Morbidity and mortality factors in key deer (Odocoileus virginianus clavium). J Wild Dis. 2002;38(4):685-92.

37. San-Blas G, Nino-Vega G, Iturriaga T. Paracoccidioides brasiliensis and paracoccidioidomycosis: molecular approaches to morphogenesis, diagnosis, epidemiology, 
taxonomy and genetics. Med Mycol. 2002;40(3):225-42.

38. Rocha VJ, Reis NR, Sekiama ML. Dieta e dispersão de sementes por Cerdocyon thous (Linnaeus) (Carnívora, Canidae), em um fragmento florestal no Paraná, Brasil. Rev Bras Zool. 2004;21(4):8716.

39. Marinho-Filho J. Mamíferos da Serra do Japi. In: Morellato LPC. História natural da Serra do Japi: ecologia e preservação de uma área florestal no sudeste do Brasil. Campinas: Editora da UNICAMP/FAPESP; 1992. P. 264-87.

40. Cherem JJ, Kammers M, Ghizoni-Jr IR, Martins A. Mamíferos de médio e grande porte atropelados em rodovias do Estado de Santa Catarina, sul do Brasil. Biotemas. 2007;20(3):81-96.

41. Nowak RM. Walker's mammals of the world. 6 ed. Baltimore: The Johns Hopkins University Press; 1999. 836 p. 1 vol.

42. Montenegro MR, Franco M. Pathology. In: Franco M, Lacaz CS, Restrepo-Moreno A, Del Negro G, editors. Paracoccidioidomycosis. Boca Raton: CRC Press; 1994. p. 131-50.

43. Câmara T, Murta R. Mamíferos da Serra do Cipó. Belo Horizonte: PUC-Minas/Museu de Ciências Naturais; 2003. 129 p.

44. Forrester DJ. Parasites and diseases of wild mammals in Florida. Florida: University Press of Florida; 1992. 459 p.

45. Silva-Vergara ML, Martinez R, Malta MEB, Ramirez LE, Franco FA. The marsupial Didelphis albiventris is an improbable host of Paracoccidioides brasiliensis in an endemic area of Paracoccidioidomycosis in Minas Gerais, Brazil. Mem Inst Oswaldo Cruz. 2001;96(6):771-2.

46. Acha PN, Szyfres B. Zoonosis y enfermedades transmisibles comunes al hombre y a los animales. 2 ed. Washington: Organizacion Panamericana de Salud Publica; 1986. 989 p.

47. Emmons CW, Ashburn LL. The isolation of
Haplosporangium parvum n. sp. and Coccidioides immitis from wild rodents. Public Health Rep. 1942;57(46): 1715-27.

48. Ajello L, Padhye AA, Sukroongreung S, Nilakul $\mathrm{CH}$, Tantimavanic S. Occurrence of Penicillium marneffei infections among wild bamboo rats in Thailand. Mycopathologia. 1995;131(1):1-8.

49. Chariyalertsak S, Vanittanakom P, Nelson KE, Sirisanthana T, Vanittanakom N. Rhizomys sumatrensis and Cannomys badius, new natural animal hosts of Penicillium marneffei. J Med Vet Mycol. 1996;34(2):105-10.

50. Berbert AL, Faria GG, Gennari-Cardoso ML, Silva MM, Minco JR, Loyola AM. Histological and serological evidence of experimental paracoccidioidomycosis in Calomys callosus (Rodentia: Cricetidae). Int J Exp Pathol. 2007;88(1):55-62.

51. Feldhammer GA, Drickamer LC, Vessey SH, Merritt JF, Krajewski C. Mammalogy: adaptation, diversity and ecology. Dubuque: McGraw-Hill; 1999. p. 302-13.

52. Melo ES, Santos-Filho M. Efeitos da BR-070 na província serrana de Cáceres, Mato Grosso, sobre a comunidade de vertebrados silvestres. Rev Bras Zootec. 2007;9(2):185-92.

53. Hubalék Z, Nesvadbova J, Halouzka J. Emmonsiosis of rodents in an agroecosystem. Med Mycol. 1998;36(6):387-90.

54. Zlatonov Z, Genov T. Isolation of Emmonsia crescens Emmons et Jellison 1960 from small mammals in Bulgaria. Mycopathologia. 1975;56(1):1-3.

55. KrivanecK, OtcenasekM,SlaisJ.Adiaspiromycosis in large free living carnivores. Mycopathologia. 1976;58(1):21-5.

56. Santos VM. Comportamento em cultura e diagnóstico morfológico da Emmonsia crescens em tatus. Rev Soc Bras Med Trop. 1999;32(3):307. 